\title{
SPAK and OSR1 Sensitive Cell Membrane Protein Abundance and Activity of KCNQ1/E1 K+ Channels
}

\author{
Bernat Elvira ${ }^{\mathrm{a}}$ Jamshed Warsi ${ }^{\mathrm{a}} \quad$ Myriam Fezai $^{\mathrm{a}}$ Carlos Munoz ${ }^{\mathrm{b}}$ Florian Lang ${ }^{\mathrm{a}}$ \\ aDepartment of Physiology I, University of Tübingen, Tübingen, Germany

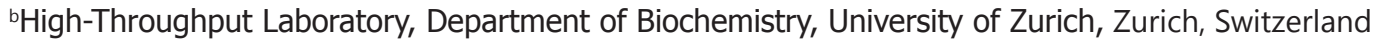

Key Words

$\mathrm{K}^{+}$channel - Oxidative stress-responsive kinase $1 \cdot \mathrm{SPS} 1$-related proline/alanine-rich kinase $•$ WNK

\begin{abstract}
Background/Aims: KCNQ1/E1 channels are expressed in diverse tissues and serve a variety of functions including endolymph secretion in the inner ear, cardiac repolarization, epithelial transport and cell volume regulation. Kinases involved in regulation of epithelial transport and cell volume include SPAK (SPS1-related proline/alanine-rich kinase) and OSR1 (oxidative stressresponsive kinase 1), which are under control of WNK (with-no-K[Lys]) kinases. The present study explored whether KCNQ1/E1 channels are regulated by SPAK and/or OSR1. Methods: CRNA encoding KCNQ1/E1 was injected into Xenopus oocytes with or without additional injection of cRNA encoding wild-type SPAK, constitutively active T233ESPAK, WNK insensitive T233ASPAK,

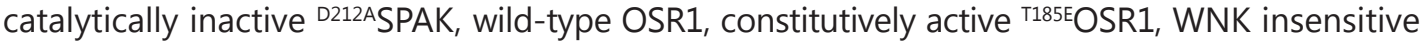
${ }^{T 185 A}$ OSR1 and catalytically inactive ${ }^{D 164 A} \mathrm{OSR} 1$. Voltage gated $\mathrm{K}^{+}$channel activity was quantified utilizing dual electrode voltage clamp and KCNQ1/E1 channel protein abundance in the cell membrane utilizing chemiluminescence of KCNQ1/E1 containing an extracellular Flag tag epitope (KCNQ1-Flag/E1). Results: KCNQ1/E1 activity and KCNQ1-Flag/E1 protein abundance

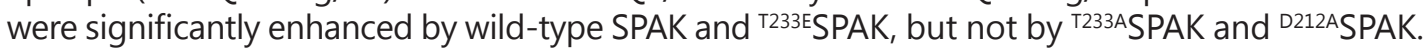
Similarly, KCNQ1/E1 activity and KCNQ1-Flag/E1 protein abundance were significantly increased by wild-type OSR1 and ${ }^{T 185 E O S R 1}$, but not by ${ }^{\mathrm{T} 185 A} \mathrm{OSR} 1$ and ${ }^{D 164 A} \mathrm{OSR} 1$. Conclusions: SPAK and OSR1 participate in the regulation of KCNQ1/E1 protein abundance and activity.
\end{abstract}

Copyright @ 2015 S. Karger AG, Basel

\section{Introduction}

$\mathrm{K}^{+}$channel subunits KCNE1 or KCNQ1 are expressed in several tissues including heart [1, 2], skeletal muscle [3], stria vascularis of the inner ear [4], renal proximal tubule [5], gastric parietal cells [6-8], intestine [5, 6, 8-11] and hepatocytes [12-14]. KCNQ1/E1 are critically important for hearing [4] and cardiac repolarisation [1,2,15]. Loss of function mutations of

B. Elvira and J. Warsi contributed equally and thus share first authorship.

Prof. Dr. Florian Lang

KARGER 125
Department of Physiology, University of Tübingen, Gmelinstr. 5, D-72076 Tübingen (Germany)

Tel. +49 7071/2972194, Fax +49 7071/295618, E-Mail florian.lang@uni-tuebingen.de 
KCNQ1/E1 are associated with hearing loss and cardiac arrhythmia [1, 2, 16]. KCNQ1 gene variants are further associated with diabetes $[17,18]$. Gene targeted mice lacking KCNQ1 suffer from severe impairment of hearing [19,20], of gastric acid secretion [20, 21], and of intestinal electrolyte and substrate transport [22]. KCNQ1 channels further participate in cell volume regulation $[13,14,23-25]$.

Kinases involved in cell volume regulatory ion transport include SPAK (SPS1-related proline/alanine-rich kinase) [26-28] and OSR1 (oxidative stress-responsive kinase 1) [29, 30]. The kinases further participate in the regulation of epithelial ion transport and blood pressure [31]. The kinases are under control of WNK (with-no-K[Lys]) kinases [26, 3235], which are similarly implicated in the regulation of ion transport and blood pressure [36-40]. SPAK and OSR1 are powerful stimulators of $\mathrm{NaCl}$ (NCC) and $\mathrm{Na}^{+}, \mathrm{K}^{+}, 2 \mathrm{Cl}^{-}$(NKCC) cotransporters [29-33, 36, 41-49] as well as several ion channels [50-53]. Genetic defects of WNK kinases may result in Gordon's syndrome, which is characterized by hypertension and hyperkalemia [34, 35, 54, 55].

The present study explored, whether SPAK and/or OSR1 participate in the regulation of KCNQ1/E1 K ${ }^{+}$channels. To this end, KCNQ1/E1 was expressed in Xenopus oocytes without or with additional expression of the kinases. The voltage gated $\mathrm{K}^{+}$current was determined in those oocytes by dual electrode voltage clamp and the channel protein abundance in the cell membrane utilizing chemiluminescence.

\section{Materials and Methods}

\section{Ethical Statement}

All experiments conform with the 'European Convention for the Protection of Vertebrate Animals used for Experimental and other Scientific Purposes' (Council of Europe No 123, Strasbourg 1985) and were conducted according to the German law for the welfare of animals. Surgical procedures on the adult Xenopus laevis were reviewed and approved by the respective government authority of the state Baden-Württemberg (Regierungspräsidium) prior to the start of the study (Anzeige für Organentnahme nach 36).

\section{Constructs}

Constructs encoding human wild-type KCNQ1/KCNE1 [56] human wild-type KCNQ1-Flag carrying an

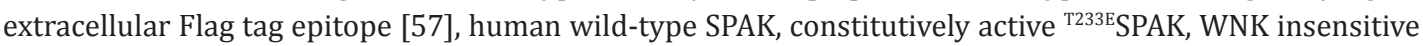

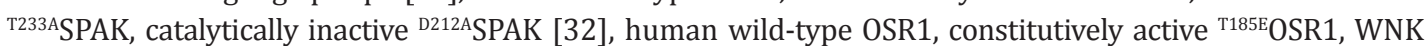
insensitive ${ }^{\mathrm{T} 185 \mathrm{~A}}$ OSR1 and catalytically inactive ${ }^{\mathrm{D} 164 \mathrm{~A}}$ OSR1[58], were used for generation of cRNA as described previously $[59,60]$. The constructs were a kind gift from Dario Alessi (University of Dundee).

\section{Voltage clamp in Xenopus oocytes}

Xenopus oocytes were prepared as previously described [61, 62]. 4.5 ng cRNA encoding KCNQ1, 1.5 ng cRNA encoding KCNE1 and 10 ng cRNA encoding wild-type, constitutively active or inactive kinase were injected on the same day after preparation of the oocytes. The oocytes were maintained at $17^{\circ} \mathrm{C}$ in ND96-A, a solution containing (in mM): $88.5 \mathrm{NaCl}, 2 \mathrm{KCl}, 1 \mathrm{MgC1}_{2}, 1.8 \mathrm{CaC1}_{2}, 5 \mathrm{HEPES}, 5$ sodium pyruvate $\left(\mathrm{C}_{3} \mathrm{H}_{3} \mathrm{NaO}_{3}\right)$, Gentamycin (100 mg/l), Tetracycline (50 mg/l), Ciprofloxacin (1.6 mg/l), Theophiline (90 mg/l) and pH7.4 $[63,64]$. The voltage clamp experiments were performed at room temperature 3 days after the first injection $[65,66]$. KCNQ1/E1 channel currents were elicited every $3 \mathrm{~s}$ with $5 \mathrm{~s}$ pulses from -120 to $+80 \mathrm{mV}$ in 8 second increments of $20 \mathrm{mV}$ steps from a holding potential of $-80 \mathrm{mV}$. The data were filtered at $2 \mathrm{kHz}$ and recorded with a Digidata A/D-D/A converter (1322A Axon Instruments) and Clampex 9.2 software for data acquisition and analysis (Axon Instruments) [67-69]. The control superfusate (ND96-B) contained (in $\mathrm{mM}$ ): $93.5 \mathrm{NaCl}, 2 \mathrm{KCl}, 1.8 \mathrm{CaCl}_{2}, 1 \mathrm{MgCl}_{2} 2.5 \mathrm{NaOH}$ and 5 HEPES, $\mathrm{pH}$ 7.4. The flow rate of the superfusion was approx. $20 \mathrm{ml} / \mathrm{min}$, and a complete exchange of the bath solution was reached within about $10 \mathrm{~s}$ [70-72].

Detection of KCNQ1-Flag/E1 cell surface expression by chemiluminescence

To determine KCNQ1-Flag/E1 cell surface expression by chemiluminescence, the oocytes were incubated with primary monoclonal mouse anti-Flag antibody (1:200, Sigma Aldrich) and subsequently 


\begin{tabular}{|c|c|c|}
\hline Cellular Physiology & Cell Physiol Biochem 2015;37:2032-2042 & \\
\hline and Biochemistry & $\begin{array}{l}\text { Dol: } 10.1159 / 000438563 \\
\text { Published online: November 20, } 2015\end{array}$ & $\begin{array}{l}\text { O } 2015 \text { S. Karger AG, Basel } \\
\text { www.karger.com/cpb }\end{array}$ \\
\hline
\end{tabular}

with secondary, HRP-conjugated anti-mouse IgG antibody (1:2500, GE Healthcare Life Sciences). Individual oocytes were placed in 96 well plates with $20 \mu$ l of SuperSignal ELISA Femto Maximum Sensitivity Substrate (Pierce, Rockford, IL, USA) and chemiluminescence of single oocytes was quantified in a luminometer (Walter Wallac 2 plate reader, Perkin Elmer, Juegesheim, Germany) by integrating the signal over a period of $1 \mathrm{~s}$. Results display normalized arbitrary light units. Integrity of the measured oocytes was assessed by visual control after the measurement to avoid unspecific light signals from the cytosol [73, 74].

\section{Statistical analysis}

Data are provided as means $\pm S E M, n$ represents the number of oocytes investigated. As different batches of oocytes may yield different results, comparisons were always made within a given oocyte batch. All voltage clamp experiments were repeated with at least 3 batches of oocytes; in all repetitions qualitatively similar data were obtained. Data were tested for significance using ANOVA (Tukey test or Kruskal-Wallis test) or t-test, as appropriate. Results with $\mathrm{p}<0.05$ were considered statistically significant.

\section{Results}

The present study explored the putative influence of SPAK (SPS1-related proline/ alanine-rich kinase) and/or OSR1 (oxidative stress-responsive kinase 1) on the function of KCNQ1/E1 K $\mathrm{K}^{+}$channels.

In a first series of experiments cRNA encoding KCNQ1/E1 was injected into Xenopus oocytes with or without additional injection of cRNA encoding wild-type SPAK. The $\mathrm{K}^{+}$currents in those oocytes were determined by dual electrode voltage clamp experiments. As illustrated in Fig. 1, the $\mathrm{K}^{+}$currents were negligible in water-injected oocytes or in oocytes expressing SPAK alone, indicating that the oocytes did not express appreciable

Fig. 1. Coexpression of wild-type SPAK increased the $\mathrm{K}^{+}$current in KCNQ1/E1expressing Xenopus oocytes. A: Representative original tracings showing currents in Xenopus oocytes injected with water (a), expressing SPAK alone (b), expressing KCNQ1/E1 alone (c) or expressing KCNQ1/ E1 with additional coexpression of wildtype SPAK (d). The voltage protocol is shown (not to scale).

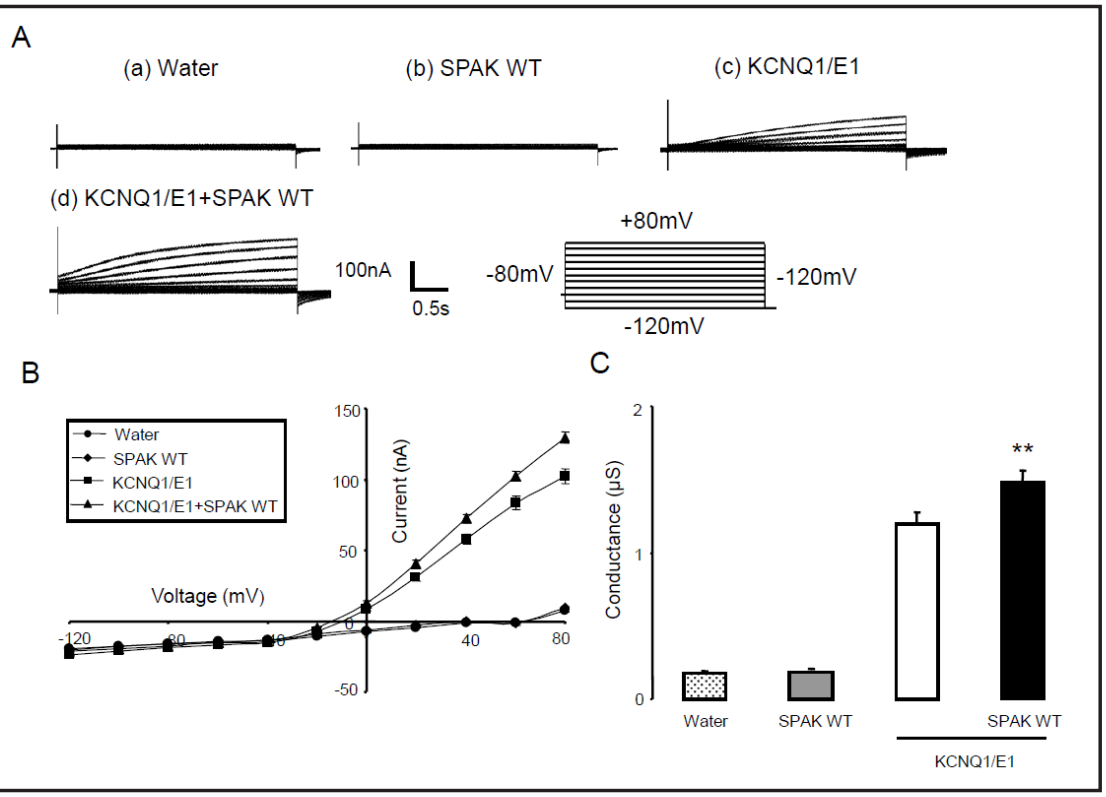
Currents were activated by depolarization from -120 to $+80 \mathrm{mV}$ in 8 second increments of $20 \mathrm{mV}$ steps from a holding potential of $-80 \mathrm{mV}$. B: Arithmetic means \pm SEM $(n=20-30)$ of the current (I) as a function of the potential difference across the cell membrane (V) in Xenopus oocytes injected with water (black circles), expressing SPAK alone (black diamonds), expressing KCNQ1/E1 alone (black squares) or expressing KCNQ1/ E1 with SPAK (black triangles). C: Arithmetic means \pm SEM $(n=20-30)$ of the conductance calculated by linear fit of I/V-curves shown in B between $20 \mathrm{mV}$ and $50 \mathrm{mV}$ in Xenopus oocytes injected with water (dotted bar), expressing SPAK alone (grey bar) or expressing KCNQ1/E1 (right bars) without (white bar) or with (black bar) additional coexpression of wild-type SPAK. ** $(\mathrm{p}<0.01)$ indicates statistically significant difference from oocytes expressing KCNQ1/E1 alone.

\section{KARGER}




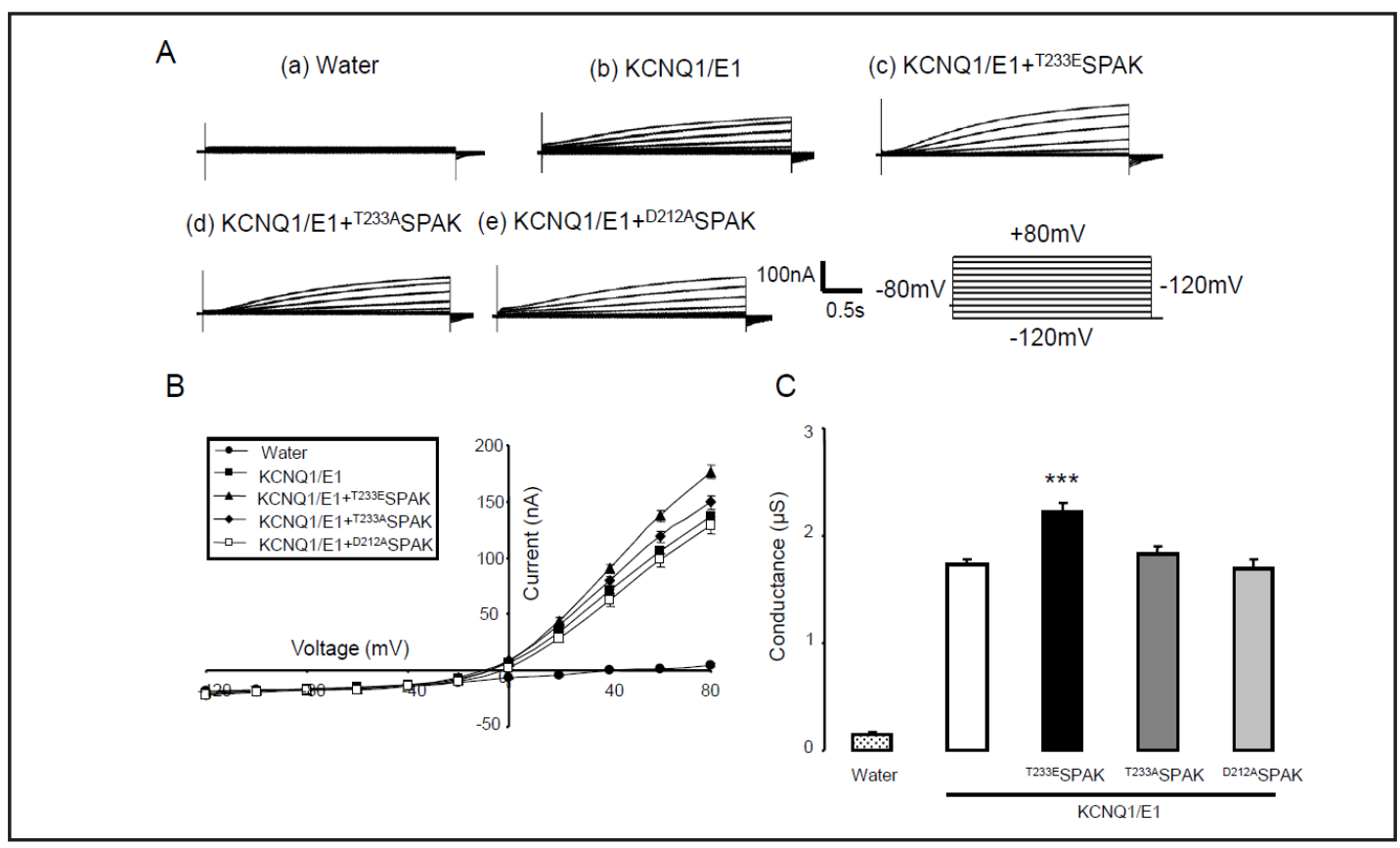

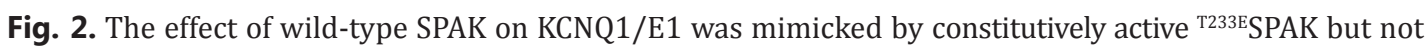
by WNK insensitive ${ }^{\mathrm{T} 233 \mathrm{~S}} \mathrm{SPAK}$ or catalytically inactive ${ }^{\mathrm{D} 212 \mathrm{~S} S P A K}$. A: Representative original tracings showing currents in Xenopus oocytes injected with water (a) expressing KCNQ1/E1 alone (b), or expressing KCNQ1/

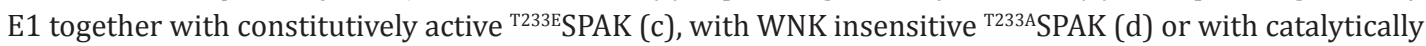
inactive ${ }^{\text {D212A }}$ SPAK (e). B: Arithmetic means \pm SEM $(n=22-35)$ of the current (I) as a function of the potential difference across the cell membrane (V) in Xenopus laevis oocytes injected with water (black circles), expressing KCNQ1/E1 alone (black squares) or expressing KCNQ1/E1 together with constitutively active

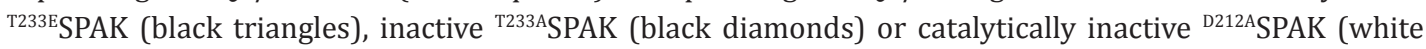
squares). C: Arithmetic means \pm SEM $(n=22-35)$ of the conductance calculated by linear fit of I/V-curves shown in B between $20 \mathrm{mV}$ and $50 \mathrm{mV}$ in Xenopus oocytes injected with water (dotted bar), expressing KCNQ1/E1 alone (white bar), expressing KCNQ1/E1 with constitutively active T233ESPAK (black bar), or expressing KCNQ1/E1 with inactive ${ }^{\mathrm{T} 233 \mathrm{~A}} \mathrm{SPAK}$ (dark grey bar), or ${ }^{\mathrm{D} 212 \mathrm{~A}} \mathrm{SPAK}$ (light grey bar). $* * *(\mathrm{p}<0.001)$ indicates statistically significant difference from oocytes expressing KCNQ1/E1 alone.

Fig. 3. SPAK increased KCNQ1-Flag/E1 protein abundance within the oocyte membrane. Arithmetic means \pm SEM ( $n=86-95)$ of normalized KCNQ1-Flag/ E1 chemiluminescence in Xenopus oocytes injected with water (dotted bar), expressing KCNQ1-Flag/ E1 alone (white bar) or expressing KCNQ1-Flag/ E1 together with wild-type SPAK (black bar). For normalization, the chemiluminescence was divided by the chemiluminescence of oocytes expressing KCNQ1-Flag/E1 alone. ** $(\mathrm{p}<0.01) \quad$ indicates statistically significant difference from oocytes expressing KCNQ1-Flag/E1 alone.

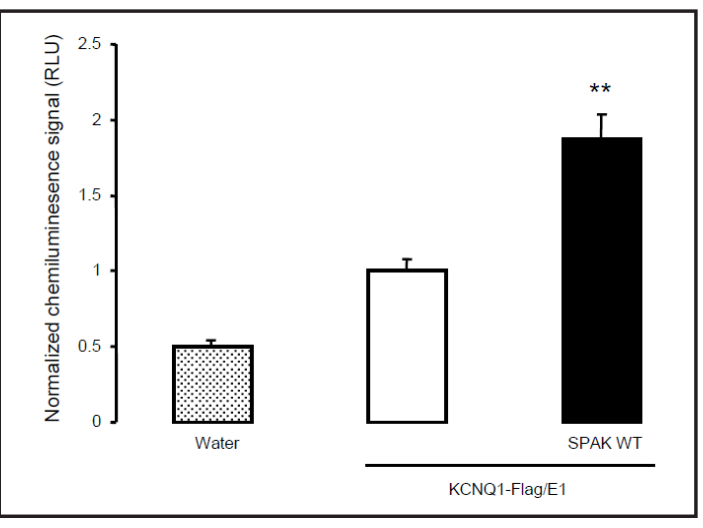

voltage gated $\mathrm{K}^{+}$channels. In contrast, large voltage gated $\mathrm{K}^{+}$currents were observed in oocytes expressing KCNQ1/E1. The additional coexpression of wild-type SPAK was followed by a significant increase of the voltage gated $\mathrm{K}^{+}$currents.

In a next series of experiments cRNA encoding KCNQ1/E1 was injected into Xenopus oocytes with or without additional injection of cRNA encoding constitutively active ${ }^{\text {T233ESPAK }}$

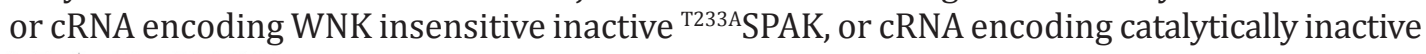
KARGER 
A

(a) Water

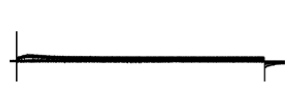

(d) KCNQ1/E1+OSR1 WT + $+80 \mathrm{mV}$

(b) OSR1 WT

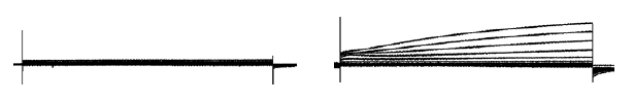

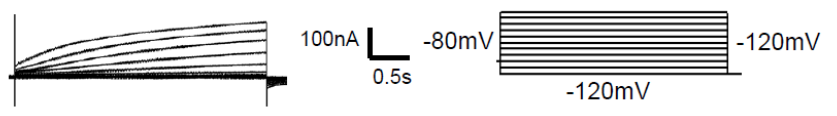

B

C
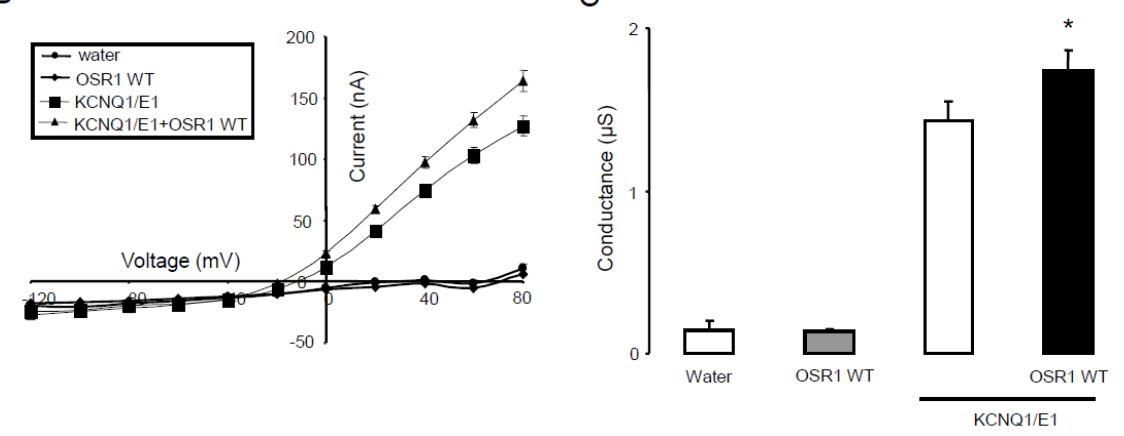

Fig. 4. Coexpression of wild-type OSR1 increased the $\mathrm{K}^{+}$current in KCNQ1/E1-expressing Xenopus oocytes. A: Representative original tracings showing currents in Xenopus oocytes injected with water (a), expressing OSR1 alone (b), expressing KCNQ1/E1 alone (c) or expressing KCNQ1/E1 with additional coexpression of wild-type OSR1 (d). The voltage protocol is shown (not to scale). Currents were activated by depolarization from -120 to $+80 \mathrm{mV}$ in 20 second increments of $20 \mathrm{mV}$ steps from a holding potential of $-80 \mathrm{mV}$. B: Arithmetic means \pm SEM $(\mathrm{n}=21-32)$ of the current (I) as a function of the potential difference across the cell membrane (V) in Xenopus oocytes injected with water (black circles), expressing OSR1 alone (black diamonds), expressing KCNQ1/E1 alone (black squares) or expressing KCNQ1/E1 with OSR1 (black triangles). C: Arithmetic means \pm SEM $(n=21-32)$ of the conductance calculated by linear fit of I/V-curves shown in B between $20 \mathrm{mV}$ and $50 \mathrm{mV}$ in Xenopus oocytes injected with water (dotted bar), expressing OSR1 alone (grey bar) or expressing KCNQ1/E1 (right bars) without (white bar) or with (black bar) additional coexpression of wild-type OSR1. ${ }^{*}(\mathrm{p}<0.05)$ indicates statistically significant difference from oocytes expressing KCNQ1/E1 alone.

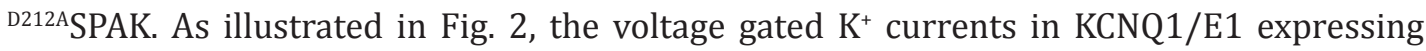
oocytes was significantly increased by coexpression of ${ }^{\mathrm{T} 233 \mathrm{SP}}{ }^{\mathrm{S} A K}$, but neither by coexpression of ${ }^{\mathrm{T} 233 \mathrm{~A}} \mathrm{SPAK}$, nor by coexpression of ${ }^{\mathrm{D} 212 \mathrm{~A}} \mathrm{SPAK}$.

A next series of experiments tested, whether the increase of KCNQ1/E1 channel activity following expression of SPAK in KCNQ1/E1 expressing oocytes was paralleled by increase of channel protein abundance in the cell membrane. In order to quantify KCNQ1/E1 protein abundance in the cell membrane, chemiluminesence was employed. To this end, KCNQ1/ E1 was tagged with an extracellular Flag tag epitope (KCNQ1-Flag/E1) allowing detection of the channel protein with an antibody directed against this epitope. As illustrated in Fig. 3, coexpression of wild-type SPAK significantly increased the KCNQ1-Flag/E1 protein abundance in the cell membrane of Xenopus oocytes.

An additional series of experiments elucidated the effect of OSR1 on KCNQ1/E1 channel activity and protein abundance. As illustrated in Fig. 4, the voltage gated $\mathrm{K}^{+}$current was in KCNQ1/E1 expressing oocytes significantly enhanced by the coexpression of wild-type OSR1. As shown in Fig. 5, the effect of wild-type OSR1 on the voltage gated $\mathrm{K}^{+}$current in KCNQ1/E1 expressing oocytes was mimicked by constitutively active ${ }^{\text {T185E }}$ OSR1 but neither by the WNK insensitive inactive ${ }^{\text {T185A }}$ OSR1 nor by the catalytically dead ${ }^{\mathrm{D} 164 \mathrm{~A}}$ OSR1 (Fig. 5).

The effect of wild-type OSR1 expression on KCNQ1-Flag/E1 protein abundance in the cell membrane of KCNQ1-Flag/E1 expressing Xenopus oocytes was quantified by 
A
(a) Water

(b) KCNQ1/E1

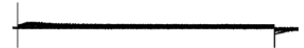

(d) KCNQ1/E1+ ${ }^{\mathrm{T} 185 \mathrm{~A} O S R} 1$

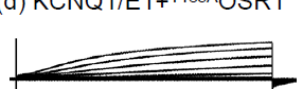

(e) KCNQ1/E1+D164AOSR1

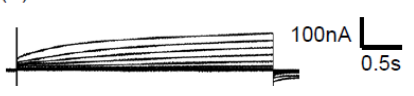

B

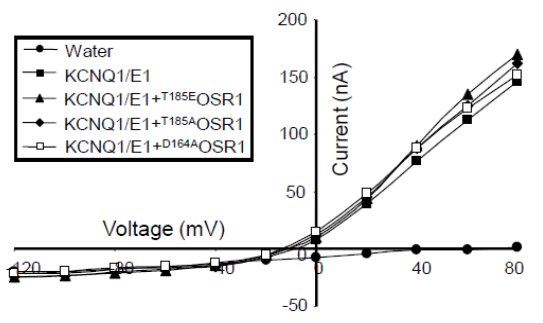

C

(c) KCNQ1/E1+T185EOSR1
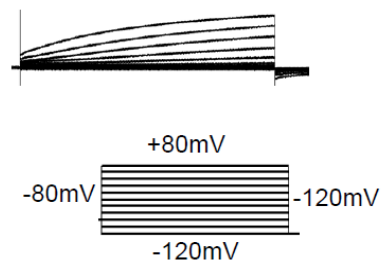

$-120 \mathrm{mV}$

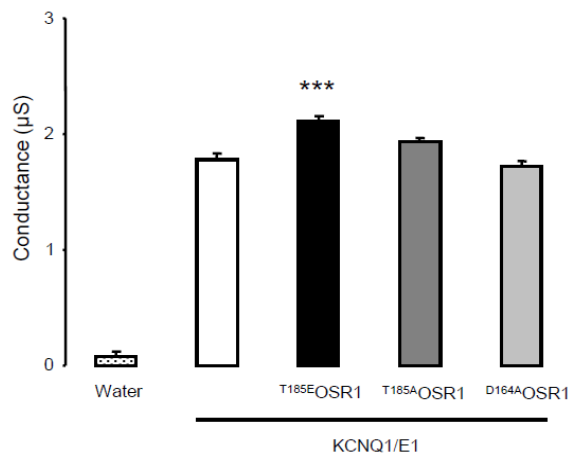

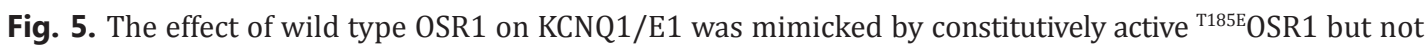
by WNK insensitive ${ }^{\mathrm{T} 185 \mathrm{~A} A} \mathrm{OSR} 1$ or catalytically inactive ${ }^{\mathrm{D} 164 \mathrm{~A}} \mathrm{OSR} 1$. A: Representative original tracings showing currents in Xenopus oocytes injected with water (a), expressing KCNQ1/E1 alone (b), expressing KCNQ1/ E1 together with constitutively active ${ }^{\mathrm{T} 185 \mathrm{E}} \mathrm{OSR} 1$ (c) or expressing KCNQ1/E1 with WNK insensitive ${ }^{\mathrm{T} 185 \mathrm{~A}} \mathrm{OSR} 1$ (d) or catalytically inactive ${ }^{\text {D164A }}$ OSR1 (e). B: Arithmetic means \pm SEM ( $\left.n=15-33\right)$ of the current (I) as a function of the potential difference across the cell membrane (V) in Xenopus laevis oocytes injected with water (black circles), expressing KCNQ1/E1 alone (black squares) or expressing KCNQ1/E1 together with constitutively active ${ }^{\text {T185E }}$ OSR 1 (black triangles), WNK insensitive ${ }^{\text {T185A }}$ OSR1 (black diamonds) or catalytically inactive ${ }^{\text {D164A } O S R 1 ~(w h i t e ~ s q u a r e s) . ~ C: ~ A r i t h m e t i c ~ m e a n s ~} \pm$ SEM $(n=15-33)$ of the conductance calculated by linear fit of I/V-curves shown in B between $20 \mathrm{mV}$ and $50 \mathrm{mV}$ in Xenopus oocytes injected with water (dotted bar), expressing KCNQ1/E1 alone (white bar), expressing KCNQ1/E1 with constitutively active ${ }^{\mathrm{T} 185 \mathrm{E}} \mathrm{OSR} 1$

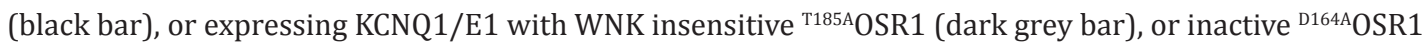
(light grey bar). ${ }^{* * *}(\mathrm{p}<0.001)$ indicates statistically significant difference from oocytes expressing KCNQ1/ E1 alone.

Fig. 6. OSR1 increased KCNQ1-Flag/E1 protein abundance within the oocyte membrane. Arithmetic means \pm SEM $(n=77-92)$ of normalized KCNQ1-Flag/ E1 chemiluminescence in Xenopus oocytes injected with water (dotted bar), expressing KCNQ1-Flag/ E1 alone (white bar) or expressing KCNQ1-Flag/ E1 together with wild-type OSR1 (black bar). For normalization, the chemiluminescence was divided by the chemiluminescence of oocytes expressing KCNQ1-Flag/E1 alone. ${ }^{* * *}(\mathrm{p}<0.001)$ indicates statistically significant difference from oocytes expressing KCNQ1-Flag/E1 alone.

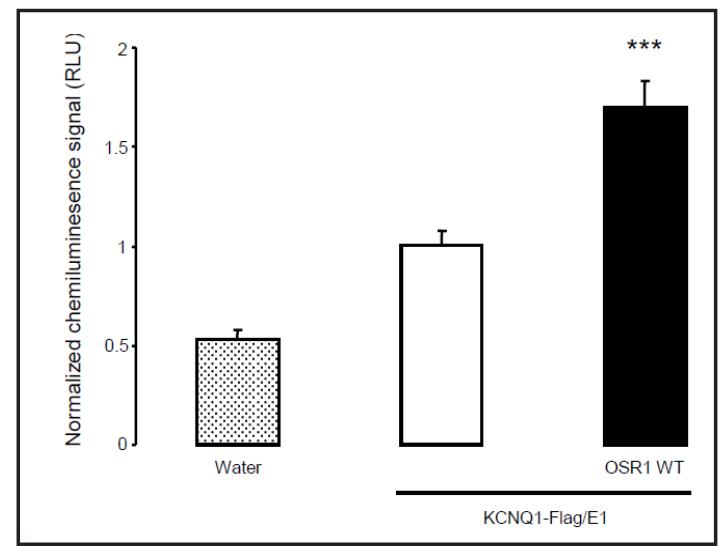

chemiluminescence. As illustrated in Fig. 6, coexpression of OSR1 significantly enhanced the KCNQ1-Flag/E1 protein abundance in the cell membrane. 


\begin{tabular}{|c|c|c|}
\hline Cellular Physiology & Cell Physiol Biochem 2015;37:2032-2042 & \\
\hline and Biochemistr & $\begin{array}{l}\text { DOI: } 10.1159 / 000438563 \\
\text { Published online: November 20, } 2015\end{array}$ & $\begin{array}{l}\text { O } 2015 \text { S. Karger AG, Base } \\
\text { www.karger.com/cpb }\end{array}$ \\
\hline
\end{tabular}

\section{Discussion}

The present study discloses SPAK/OSR1 sensitivity of KCNQ1/E1 $\mathrm{K}^{+}$channels. Coexpression of either SPAK or OSR1 increases the KCNQ1/E1 channel protein abundance in the cell membrane and thus enhances the respective $\mathrm{K}^{+}$current in KCNQ1/E1 expressing oocytes. In theory, SPAK/OSR1 could delay the retrieval of channel protein from the cell membrane or accelerate the insertion of new channel protein into the cell membrane. The effects of wild-type SPAK is mimicked by constitutively active ${ }^{\mathrm{T} 233 \mathrm{E}} \mathrm{SPAK}$ but not by

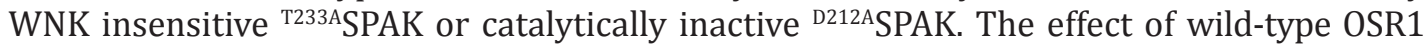
is mimicked by constitutively active ${ }^{\mathrm{T} 185 \mathrm{E}}$ OSR1, but not by WNK insensitive ${ }^{\mathrm{T} 185 \mathrm{~A} A S R 1}$ or catalytically inactive ${ }^{\mathrm{D} 164 \mathrm{~A}}$ OSR1. Accordingly, activation by WNK kinases of SPAK or OSR1 is required for activation of the kinases. Moreover, kinase activity of SPAK and OSR1 are required for the effect on KCNQ1/E1 activity. This observation does not necessarily mean that SPAK and OSR1 are effective by directly phosphorylating the channel protein. Instead, the kinases may be effective by phosphorylating other regulators of the channel protein thus indirectly modifying its regulation.

In theory, the kinases could influence KCNQ1/E1 channel by modifying cell volume and/ or cytosolic $\mathrm{K}^{+}$concentration. SPAK and OSR1 stimulate the $\mathrm{NaCl}$ cotransporter as well as the $\mathrm{Na}^{+}, \mathrm{K}^{+}, 2 \mathrm{Cl}^{-}$cotransporter and inhibit $\mathrm{KCl}$ cotransporters thus fostering cellular $\mathrm{K}^{+}$uptake [29-33, 36, 41-49]. The cellular accumulation of $\mathrm{KCl}$ with osmotically obliged water leads to cell swelling [75-77]. KCNQ1 channels have previously been shown to be sensitive to cell swelling [13, 14, 23-25].

The present study did not elucidate the functional significance of SPAK and OSR1 sensitive KCNQ1/E1 function. KCNQ1/E1 channels serve a variety of functions, including cardiac repolarisation $[1,2,15]$, hearing $[4,19,20]$, renal tubular transport [5], gastric acid secretion [6-8, 20,21], intestinal transport [5, 6, 8-11, 22], hepatocyte function [12-14] and metabolism $[17,18]$. The effect of SPAK and OSR1 on KCNQ1/E1 is, however, small and is not expected to disrupt any of the KCNQ1/E1 sensitive functions. Additional experimental effort is needed to define the biological significance of SPAK/OSR1-sensitive regulation of KCNQ1/ E1.

In conclusion, SPAK and OSR1 have both the potential to up-regulate KCNQ1/E1 protein abundance in the cell membrane, an effect possibly participating in the regulation of cell volume, excitability, epithelial transport and metabolism.

\section{Acknowledgements}

The authors acknowledge the meticulous preparation of the manuscript by Lejla Subasic and technical support by Elfriede Faber. This study was supported by the Deutsche Forschungsgemeinschaft, GRK 1302, SFB 773 B4/A1, La 315/13-3, and Open Access Publishing Fund of Tuebingen University.

\section{Disclosure Statement}

The authors of this manuscript state that they do not have any conflict of interests and nothing to disclose.

\section{References}

1 Barhanin J, Lesage F, Guillemare E, Fink M, Lazdunski M, Romey G: K(V)LQT1 and lsK (minK) proteins associate to form the I(Ks) cardiac potassium current. Nature 1996;384:78-80. 


\section{Cellular Physiology Cell Physiol Biochem 2015;37:2032-2042 \begin{tabular}{l|l|l}
\hline DOI: 10.1159/000438563 & (C)15 S. Karger AG, Basel
\end{tabular} and Biochemistry Published online: November 20, $2015 \quad$\begin{tabular}{l} 
www.karger.com/cpb \\
\hline
\end{tabular} \\ Elvira et al.: SPAK/OSR1 Sensitive KCNQ1/E1}

2 Sanguinetti MC, Curran ME, Zou A, Shen J, Spector PS, Atkinson DL, Keating MT: Coassembly of K(V)LQT1 and minK (IsK) proteins to form cardiac I(Ks) potassium channel. Nature 1996;384:80-83.

3 Finsterer J, Stollberger C: Skeletal muscle involvement in congenital long QT syndrome. Neurol Sci 2004;25:238-240.

4 Wangemann P: Supporting sensory transduction: cochlear fluid homeostasis and the endocochlear potential. J Physiol 2006;576:11-21.

5 Vallon V, Grahammer F, Richter K, Bleich M, Lang F, Barhanin J, Volkl H, Warth R: Role of KCNE1-dependent K+ fluxes in mouse proximal tubule. J Am Soc Nephrol 2001;12:2003-2011.

6 Dedek K, Waldegger S: Colocalization of KCNQ1/KCNE channel subunits in the mouse gastrointestinal tract. Pflugers Arch 2001;442:896-902.

7 Grahammer F, Herling AW, Lang HJ, Schmitt-Graff A, Wittekindt OH, Nitschke R, Bleich M, Barhanin J, Warth R: The cardiac K+ channel KCNQ1 is essential for gastric acid secretion. Gastroenterology 2001;120:13631371.

8 Heitzmann D, Grahammer F, von Hahn T, Schmitt-Graff A, Romeo E, Nitschke R, Gerlach U, Lang HJ, Verrey F, Barhanin J, Warth R: Heteromeric KCNE2/KCNQ1 potassium channels in the luminal membrane of gastric parietal cells. J Physiol 2004;561:547-557.

9 Nicolas M, Dememes D, Martin A, Kupershmidt S, Barhanin J: KCNQ1/KCNE1 potassium channels in mammalian vestibular dark cells. Hear Res 2001;153:132-145.

10 Schroeder BC, Waldegger S, Fehr S, Bleich M, Warth R, Greger R, Jentsch TJ: A constitutively open potassium channel formed by KCNQ1 and KCNE3. Nature 2000;403:196-199.

11 Sugimoto T, Tanabe Y, Shigemoto R, Iwai M, Takumi T, Ohkubo H, Nakanishi S: Immunohistochemical study of a rat membrane protein which induces a selective potassium permeation: its localization in the apical membrane portion of epithelial cells. J Membr Biol 1990;113:39-47.

12 Demolombe S, Franco D, de Boer P, Kuperschmidt S, Roden D, Pereon Y, Jarry A, Moorman AF, Escande D: Differential expression of KvLQT1 and its regulator IsK in mouse epithelia. Am J Physiol Cell Physiol 2001;280:C359-372.

13 Lan WZ, Abbas H, Lemay AM, Briggs MM, Hill CE: Electrophysiological and molecular identification of hepatocellular volume-activated K+ channels. Biochim Biophys Acta 2005;1668:223-233.

14 Lan WZ, Wang PY, Hill CE: Modulation of hepatocellular swelling-activated K+ currents by phosphoinositide pathway-dependent protein kinase C. Am J Physiol Cell Physiol 2006;291:C93-103.

15 Knollmann BC, Casimiro MC, Katchman AN, Sirenko SG, Schober T, Rong Q, Pfeifer K, Ebert SN: Isoproterenol exacerbates a long QT phenotype in Kcnq1-deficient neonatal mice: possible roles for human-like Kcnq1 isoform 1 and slow delayed rectifier K+ current. J Pharmacol Exp Ther 2004;310:311318.

16 Neyroud N, Tesson F, Denjoy I, Leibovici M, Donger C, Barhanin J, Faure S, Gary F, Coumel P, Petit C, Schwartz K, Guicheney P: A novel mutation in the potassium channel gene KVLQT1 causes the Jervell and Lange-Nielsen cardioauditory syndrome. Nat Genet 1997;15:186-189.

17 Unoki H, Takahashi A, Kawaguchi T, Hara K, Horikoshi M, Andersen G, Ng DP, Holmkvist J, Borch-Johnsen K, Jorgensen T, Sandbaek A, Lauritzen T, Hansen T, Nurbaya S, Tsunoda T, Kubo M, Babazono T, Hirose H, Hayashi M, Iwamoto Y, Kashiwagi A, Kaku K, Kawamori R, Tai ES, Pedersen O, Kamatani N, Kadowaki T, Kikkawa R, Nakamura Y, Maeda S: SNPs in KCNQ1 are associated with susceptibility to type 2 diabetes in East Asian and European populations. Nat Genet 2008;40:1098-1102.

18 Yasuda K, Miyake K, Horikawa Y, Hara K, Osawa H, Furuta H, Hirota Y, Mori H, Jonsson A, Sato Y, Yamagata K, Hinokio Y, Wang HY, Tanahashi T, Nakamura N, Oka Y, Iwasaki N, Iwamoto Y, Yamada Y, Seino Y, Maegawa H, Kashiwagi A, Takeda J, Maeda E, Shin HD, Cho YM, Park KS, Lee HK, Ng MC, Ma RC, So WY, Chan JC, Lyssenko V, Tuomi T, Nilsson P, Groop L, Kamatani N, Sekine A, Nakamura Y, Yamamoto K, Yoshida T, Tokunaga K, Itakura M, Makino H, Nanjo K, Kadowaki T, Kasuga M: Variants in KCNQ1 are associated with susceptibility to type 2 diabetes mellitus. Nat Genet 2008;40:1092-1097.

19 Casimiro MC, Knollmann BC, Ebert SN, Vary JC, Jr., Greene AE, Franz MR, Grinberg A, Huang SP, Pfeifer K: Targeted disruption of the Kcnq1 gene produces a mouse model of Jervell and Lange-Nielsen Syndrome. Proc Natl Acad Sci U S A 2001;98:2526-2531. 


\section{Cellular Physiology Cell Physiol Biochem 2015;37:2032-2042 \begin{tabular}{l|l} 
and Biochemistry $\begin{array}{l}\text { DOI: 10.1159/000438563 } \\
\text { Published online: November 20, } 2015\end{array}$ & $\begin{array}{l}\text { C 2015 S. Karger AG, Basel } \\
\text { www.karger.com/cpb }\end{array}$ \\
\hline
\end{tabular} \\ Elvira et al.: SPAK/OSR1 Sensitive KCNQ1/E1}

20 Lee MP, Ravenel JD, Hu RJ, Lustig LR, Tomaselli G, Berger RD, Brandenburg SA, Litzi TJ, Bunton TE, Limb C, Francis H, Gorelikow M, Gu H, Washington K, Argani P, Goldenring JR, Coffey RJ, Feinberg AP: Targeted disruption of the Kvlqt1 gene causes deafness and gastric hyperplasia in mice. J Clin Invest 2000;106:14471455.

21 Scarff KL, Judd LM, Toh BH, Gleeson PA, Van Driel IR: Gastric H(+),K(+)-adenosine triphosphatase beta subunit is required for normal function, development, and membrane structure of mouse parietal cells. Gastroenterology 1999;117:605-618.

22 Vallon V, Grahammer F, Volkl H, Sandu CD, Richter K, Rexhepaj R, Gerlach U, Rong Q, Pfeifer K, Lang F: KCNQ1-dependent transport in renal and gastrointestinal epithelia. Proc Natl Acad Sci U S A 2005;102:17864-17869.

23 Bachmann 0, Heinzmann A, Mack A, Manns MP, Seidler U: Mechanisms of secretion-associated shrinkage and volume recovery in cultured rabbit parietal cells. Am J Physiol Gastrointest Liver Physiol 2007;292:G711-717.

24 Grunnet M, Jespersen T, MacAulay N, Jorgensen NK, Schmitt N, Pongs O, Olesen SP, Klaerke DA: KCNQ1 channels sense small changes in cell volume. J Physiol 2003;549:419-427.

25 vanTol BL, Missan S, Crack J, Moser S, Baldridge WH, Linsdell P, Cowley EA: Contribution of KCNQ1 to the regulatory volume decrease in the human mammary epithelial cell line MCF-7. Am J Physiol Cell Physiol 2007;293:C1010-1019.

26 Rafiqi FH, Zuber AM, Glover M, Richardson C, Fleming S, Jovanovic S, Jovanovic A, O'Shaughnessy KM, Alessi DR: Role of the WNK-activated SPAK kinase in regulating blood pressure. EMBO Mol Med 2010;2:63-75.

27 Castaneda-Bueno M, Gamba G: SPAKling insight into blood pressure regulation. EMBO Mol Med 2010;2:3941.

28 Yang SS, Lo YF, Wu CC, Lin SW, Yeh CJ, Chu P, Sytwu HK, Uchida S, Sasaki S, Lin SH: SPAK-knockout mice manifest Gitelman syndrome and impaired vasoconstriction. J Am Soc Nephrol 2010;21:1868-1877.

29 Lin SH, Yu IS, Jiang ST, Lin SW, Chu P, Chen A, Sytwu HK, Sohara E, Uchida S, Sasaki S, Yang SS: Impaired phosphorylation of $\mathrm{Na}(+)-\mathrm{K}(+)-2 \mathrm{Cl}(-)$ cotransporter by oxidative stress-responsive kinase-1 deficiency manifests hypotension and Bartter-like syndrome. Proc Natl Acad Sci USA 2011;108:17538-17543.

30 Villa F, Deak M, Alessi DR, van Aalten DM: Structure of the OSR1 kinase, a hypertension drug target. Proteins 2008;73:1082-1087.

31 Gagnon KB, Delpire E: Molecular physiology of SPAK and OSR1: two Ste20-related protein kinases regulating ion transport. Physiol Rev 2012;92:1577-1617.

32 Vitari AC, Deak M, Morrice NA, Alessi DR: The WNK1 and WNK4 protein kinases that are mutated in Gordon's hypertension syndrome phosphorylate and activate SPAK and OSR1 protein kinases. Biochem J 2005;391:17-24.

33 Vitari AC, Thastrup J, Rafiqi FH, Deak M, Morrice NA, Karlsson HK, Alessi DR: Functional interactions of the SPAK/OSR1 kinases with their upstream activator WNK1 and downstream substrate NKCC1. Biochem J 2006;397:223-231.

34 Glover M, Zuber AM, O'Shaughnessy KM: Hypertension, dietary salt intake, and the role of the thiazidesensitive sodium chloride transporter NCCT. Cardiovasc Ther 2011;29:68-76.

35 O'Reilly M, Marshall E, Speirs HJ, Brown RW: WNK1, a gene within a novel blood pressure control pathway, tissue-specifically generates radically different isoforms with and without a kinase domain. J Am Soc Nephrol 2003;14:2447-2456.

36 Kahle KT, Rinehart J, Lifton RP: Phosphoregulation of the Na-K-2Cl and K-Cl cotransporters by the WNK kinases. Biochim Biophys Acta 2010;1802:1150-1158.

37 Flatman PW: Cotransporters, WNKs and hypertension: an update. Curr Opin Nephrol Hypertens 2008;17:186-192.

38 Furgeson SB, Linas S: Mechanisms of type I and type II pseudohypoaldosteronism. J Am Soc Nephrol 2010;21:1842-1845.

39 Uchida S: Pathophysiological roles of WNK kinases in the kidney. Pflugers Arch 2010;460:695-702.

40 Wilson FH, Disse-Nicodeme S, Choate KA, Ishikawa K, Nelson-Williams C, Desitter I, Gunel M, Milford DV, Lipkin GW, Achard JM, Feely MP, Dussol B, Berland Y, Unwin RJ, Mayan H, Simon DB, Farfel Z, Jeunemaitre X, Lifton RP: Human hypertension caused by mutations in WNK kinases. Science 2001;293:1107-1112. 
41 Delpire E, Gagnon KB: SPAK and OSR1, key kinases involved in the regulation of chloride transport. Acta Physiol (Oxf) 2006;187:103-113.

42 Delpire E, Gagnon KB: SPAK and OSR1: STE20 kinases involved in the regulation of ion homoeostasis and volume control in mammalian cells. Biochem J 2008;409:321-331.

43 Gimenez I: Molecular mechanisms and regulation of furosemide-sensitive Na-K-Cl cotransporters. Curr Opin Nephrol Hypertens 2006;15:517-523.

44 Richardson C, Sakamoto K, de los HP, Deak M, Campbell DG, Prescott AR, Alessi DR: Regulation of the NKCC2 ion cotransporter by SPAK-OSR1-dependent and -independent pathways. J Cell Sci 2011;124:789800.

45 Gagnon KB, Delpire E: On the substrate recognition and negative regulation of SPAK, a kinase modulating Na+-K+-2Cl- cotransport activity. Am J Physiol Cell Physiol 2010;299:C614-C620.

46 Glover M, O'Shaughnessy KM: SPAK and WNK kinases: a new target for blood pressure treatment? Curr Opin Nephrol Hypertens 2011;20:16-22.

47 Huang CL, Yang SS, Lin SH: Mechanism of regulation of renal ion transport by WNK kinases. Curr Opin Nephrol Hypertens 2008;17:519-525.

48 Mercier-Zuber A, O'Shaughnessy KM: Role of SPAK and OSR1 signalling in the regulation of $\mathrm{NaCl}$ cotransporters. Curr Opin Nephrol Hypertens 2011;20:534-540.

49 Richardson C, Alessi DR: The regulation of salt transport and blood pressure by the WNK-SPAK/OSR1 signalling pathway. J Cell Sci 2008;121:3293-3304.

50 Falin RA, Miyazaki H, Strange K: C. elegans STK39/SPAK ortholog-mediated inhibition of ClC anion channel activity is regulated by WNK-independent ERK kinase signaling. Am J Physiol Cell Physiol 2011;300:C624635.

51 Falin RA, Morrison R, Ham AJ, Strange K: Identification of regulatory phosphorylation sites in a cell volumeand Ste20 kinase-dependent ClC anion channel. J Gen Physiol 2009;133:29-42.

52 Miyazaki H, Strange K: Differential regulation of a CLC anion channel by SPAK kinase ortholog-mediated multisite phosphorylation. Am J Physiol Cell Physiol 2012;302:C1702-1712.

53 Park HW, Nam JH, Kim JY, Namkung W, Yoon JS, Lee JS, Kim KS, Venglovecz V, Gray MA, Kim KH, Lee MG: Dynamic regulation of CFTR bicarbonate permeability by [Cl-]i and its role in pancreatic bicarbonate secretion. Gastroenterology 2010;139:620-631.

54 Achard JM, Disse-Nicodeme S, Fiquet-Kempf B, Jeunemaitre X: Phenotypic and genetic heterogeneity of familial hyperkalaemic hypertension (Gordon syndrome). Clin Exp Pharmacol Physiol 2001;28:1048-1052.

55 Capasso G, Cantone A, Evangelista C, Zacchia M, Trepiccione F, Acone D, Rizzo M: Channels, carriers, and pumps in the pathogenesis of sodium-sensitive hypertension. Semin Nephrol 2005;25:419-424.

56 Seebohm G, Strutz-Seebohm N, Ureche ON, Henrion U, Baltaev R, Mack AF, Korniychuk G, Steinke K, Tapken D, Pfeufer A, Kaab S, Bucci C, Attali B, Merot J, Tavare JM, Hoppe UC, Sanguinetti MC, Lang F: Long QT syndrome-associated mutations in KCNQ1 and KCNE1 subunits disrupt normal endosomal recycling of IKs channels. Circ Res 2008;103:1451-1457.

57 Seebohm G, Strutz-Seebohm N, Birkin R, Dell G, Bucci C, Spinosa MR, Baltaev R, Mack AF, Korniychuk G, Choudhury A, Marks D, Pagano RE, Attali B, Pfeufer A, Kass RS, Sanguinetti MC, Tavare JM, Lang F: Regulation of endocytic recycling of KCNQ1/KCNE1 potassium channels. Circ Res 2007;100:686-692.

58 Pathare G, Foller M, Daryadel A, Mutig K, Bogatikov E, Fajol A, Almilaji A, Michael D, Stange G, Voelkl J, Wagner CA, Bachmann S, Lang F: OSR1-Sensitive Renal Tubular Phosphate Reabsorption. Kidney Blood Press Res 2012;36:149-161.

59 Almilaji A, Munoz C, Hosseinzadeh Z, Lang F: Upregulation of $\mathrm{Na}+\mathrm{Cl}(-)$-coupled betaine/gamma-aminobutyric acid transporter BGT1 by Tau tubulin kinase 2. Cell Physiol Biochem 2013;32:334-343.

60 Munoz C, Pakladok T, Almilaji A, Elvira B, Decher N, Shumilina E, Lang F: Up-regulation of Kir2.1 (KCNJ2) by the serum \& glucocorticoid inducible SGK3. Cell Physiol Biochem 2014;33:491-500.

61 Hosseinzadeh Z, Dong L, Bhavsar SK, Warsi J, Almilaji A, Lang F: Upregulation of peptide transporters PEPT1 and PEPT2 by Janus kinase JAK2. Cell Physiol Biochem 2013;31:673-682.

62 Pakladok T, Almilaji A, Munoz C, Alesutan I, Lang F: PIKfyve sensitivity of hERG channels. Cell Physiol Biochem 2013;31:785-794.

63 Almilaji A, Honisch S, Liu G, Elvira B, Ajay SS, Hosseinzadeh Z, Ahmed M, Munoz C, Sopjani M, Lang F: Regulation of the voltage gated K channel Kv1.3 by recombinant human klotho protein. Kidney Blood Press Res 2014;39:609-622. 


\section{Cellular Physiology Cell Physiol Biochem 2015;37:2032-2042 \begin{tabular}{ll|l} 
and Biochemistry $10.1159 / 000438563$ & $\begin{array}{l}\text { D 2015 S. Karger AG, Basel } \\
\text { Published online: November 20, 2015 }\end{array}$ & \\
\cline { 2 - 3 }
\end{tabular} \\ Elvira et al.: SPAK/OSR1 Sensitive KCNQ1/E1}

64 Almilaji A, Szteyn K, Fein E, Pakladok T, Munoz C, Elvira B, Towhid ST, Alesutan I, Shumilina E, Bock CT, Kandolf R, Lang F: Down-regulation of $\mathrm{Na} / \mathrm{K}+$ atpase activity by human parvovirus B19 capsid protein VP1. Cell Physiol Biochem 2013;31:638-648.

65 Almilaji A, Sopjani M, Elvira B, Borras J, Dermaku-Sopjani M, Munoz C, Warsi J, Lang UE, Lang F: Upregulation of the creatine transporter Slc6A8 by Klotho. Kidney Blood Press Res 2014;39:516-525.

66 Fezai M, Elvira B, Borras J, Ben-Attia M, Hoseinzadeh Z, Lang F: Negative regulation of the creatine transporter SLC6A8 by SPAK and OSR1. Kidney Blood Press Res 2014;39:546-554.

67 Hosseinzadeh Z, Luo D, Sopjani M, Bhavsar SK, Lang F: Down-regulation of the epithelial Na(+) channel ENaC by Janus kinase 2. J Membr Biol 2014;247:331-338.

68 Hosseinzadeh Z, Sopjani M, Pakladok T, Bhavsar SK, Lang F: Downregulation of KCNQ4 by Janus kinase 2. J Membr Biol 2013;246:335-341.

69 Munoz C, Almilaji A, Setiawan I, Foller M, Lang F: Up-regulation of the inwardly rectifying K(+) channel Kir2.1 (KCNJ2) by protein kinase B (PKB/Akt) and PIKfyve. J Membr Biol 2013;246:189-197.

70 Warsi J, Dong L, Elvira B, Salker MS, Shumilina E, Hosseinzadeh Z, Lang F: SPAK dependent regulation of peptide transporters PEPT1 and PEPT2. Kidney Blood Press Res 2014;39:388-398.

71 Warsi J, Elvira B, Bissinger R, Shumilina E, Hosseinzadeh Z, Lang F: Downregulation of peptide transporters PEPT1 and PEPT2 by oxidative stress responsive kinase OSR1. Kidney Blood Press Res 2014;39:591-599.

72 Warsi J, Hosseinzadeh Z, Elvira B, Bissinger R, Shumilina E, Lang F: Regulation of ClC-2 activity by SPAK and OSR1. Kidney Blood Press Res 2014;39:378-387.

73 Dermaku-Sopjani M, Almilaji A, Pakladok T, Munoz C, Hosseinzadeh Z, Blecua M, Sopjani M, Lang F: Downregulation of the Na+-coupled phosphate transporter NaPi-IIa by AMP-activated protein kinase. Kidney Blood Press Res 2013;37:547-556.

74 Elvira B, Munoz C, Borras J, Chen H, Warsi J, Ajay SS, Shumilina E, Lang F: SPAK and OSR1 dependent downregulation of murine renal outer medullary K channel ROMK1. Kidney Blood Press Res 2014;39:353-360.

75 Hoffmann EK: Ion channels involved in cell volume regulation: effects on migration, proliferation, and programmed cell death in non adherent EAT cells and adherent ELA cells. Cell Physiol Biochem 2011;28:1061-1078.

76 Hoffmann EK, Lambert IH, Pedersen SF: Physiology of cell volume regulation in vertebrates. Physiol Rev 2009;89:193-277.

77 Lang F: Mechanisms and significance of cell volume regulation. J Am Coll Nutr 2007;26:613S-623S. 